\title{
Examination of the influence of macro and microscopic parameters of limestone on the effectiveness of gas phase desulphurisation according to the method of wet limestone
}

\author{
Elżbieta Romanik ${ }^{1, *}$ \\ ${ }^{1}$ Wroclaw University of Science and Technology, Faculty of Environmental Engineering, Wybrzeże \\ Wyspiańskiego 25, 50-370 Wrocław, Poland
}

\begin{abstract}
The essence of the research was to develop a correlation dependence between the degree of limestone grinding and the efficiency of boiler flue gas desulfurization. The design of the Installation of Flue Gas Desulfurization (FGD) in the slurry of ground limestone begins with the assumption (based on literature data or experience gained from previously completed and operated installations) of a certain $\mathrm{pH}$ value of this slurry in the reactor tank. The reagent is not yet indicated, its extraction location, its chemical composition, grain size and reactivity are not determined. Application practice and economics of these processes have shown that calcium reagents are the most advantageous in application because of the general availability of limestone, its large mining resources, existing infrastructure for its extraction, the network of suppliers and the purchase cost acceptable by the recipients. On a global scale, more than $90 \%$ of the flue gas desulfurization plant is treated with limestone [1]. The effectiveness of the desulfurization process is high, and some believe that the decisive influence is on the degree of limestone fragmentation dissolution rate of $\mathrm{CaCO}_{3}$ in the absorption slurry, its reactivity to absorbed $\mathrm{SO}_{2}$, the $\mathrm{pH}$ of the absorption slurry.
\end{abstract}

\section{Calcium sorbents used in flue gas desulfurization technologies}

Calcium-calcium sorbents include: in dry desulfurization methods - ground lime and lime stone, in semi-dry desulfurization methods - hydrated lime and ground lime, in wet desulfurization method - ground lime, ground limestone and chalk. The basic factors determining the sorbent quality include: the content of the active ingredient, the amount and type of impurities, fragmentation (grain size) and the crystallographic structure of the sorbent [2-4].

${ }^{*}$ Corresponding author: elzbieta.romanik@pwr.edu.pl 
Grinding is one of the most commonly used unit operations designed to prepare limestone for use in flue gas desulfurization processes. Technically it is possible to fragment the sorbent up to thousandths of a millimeter, whereas obtaining the required sorbent particle distribution is reflected in the properties of the sorbent, its quality and significantly affects the way and effects of the desulfurization process [5, 6].

Depending on the technology used, the sorbent is delivered to the flue gas desulfurization plant in the form of limestone or as ready-made limestone powder. Limestone was ground in ball mills to obtain a slurry of limestone powder containing sorbent grains below $60 \mu \mathrm{m}[3,5,7]$. The research confirms that the greater fragmentation (in the grain size $1-10 \mu \mathrm{m}$ ) significantly affects the dissolution rate of the sorbent, which enables to reduce the density of the absorber spraying and the circulation ratio of the slurry in the $\mathrm{SO}_{2}$ absorption node, increase the efficiency of flue gas desulfurization and reduce energy consumption and, consequently, the reduction of operating costs of FGD $[8,9]$.

\subsection{Parameters influencing the effectiveness of FGD working according to the wet lime method}

Each flue gas desulfurization plant has its "technological limits" that should not be passed. Numerous technical aspects of the used process media influence the effectiveness of FGD, i.e. $[10,11]$ : proper fuel preparation, design quantity and quality of fuel (e.g. calorific value, sulfur content, content of combustible parts), combustion conditions in the combustion chamber, quality of exhaust fumes corresponding to FGD operation conditions, design amount and exhaust gas quality at FGD (volumetric flue gas stream, flue gas temperature and pressure, dust content and $\mathrm{SO}_{2}, \mathrm{SO}_{3}, \mathrm{HCl}, \mathrm{HF}$ and $\mathrm{O}_{2}$ shares), design quantity and quality of the sorbent used (physico-chemical composition, grain size, $\mathrm{CaCO}_{3}$ content, contaminants, e.g. aluminosilicates, reactivity), design quantity and quality of process water (chloride content, suspension content).

\section{Experimental part}

Fifteen samples of ground unmilled burnt lime or ground milled lime, fine-grained and coarse sorbent (crumbled in lime plants) and milled in dry mills to form powdered limestone, used in boiler flue gas desulfurization using dry, semi-dry and wet methods were used for the research. Ground limestone used for research was taken from real objects, i.e. from limestone powder storage tanks, used in the flue gas desulfurization installation in several Polish power plants.

Laboratory tests of limestone, aimed at determining its suitability for the desulfurization of flue gases, especially in wet technology, consisted in determining:

- physico-chemical composition,

- grinding degree (grain size distribution),

- its reactivity to sulfur dioxide

- the rate of change in the $\mathrm{pH}$ value of its aqueous absorbing suspension

\subsection{Analysis of the chemical composition of the tested limestone samples}

The test results expressed in the form of shares of calcium oxide $\left(\mathrm{CaCO}_{3}\right)$ and shares of tested limestone samples aggregated contaminants are shown in Table. 1 
Table 1. Shares of calcium oxide and total shares of contaminants of the sample tested limestone.

\begin{tabular}{|c|c|c|}
\hline \multirow[t]{2}{*}{$\begin{array}{c}\text { Limestone sample } \\
\text { number }\end{array}$} & $\mathrm{CaCO}_{3}$ share & $\begin{array}{c}\text { Contaminants share } \\
\left(\mathrm{Fe}_{2} \mathrm{O}_{3}+\mathrm{K}_{2} \mathrm{O}+\mathrm{SO}_{3}+\mathrm{Na}_{2} \mathrm{O}+\mathrm{MgO}+\right. \\
\left.\mathrm{Al}_{2} \mathrm{O}_{3}+\mathrm{SiO}_{2}+\mathrm{NR}+\text { Moisture }\right)\end{array}$ \\
\hline & $\%$ & $\%$ \\
\hline 2 & 82.63 & 10.52 \\
\hline 3 & 90.32 & 8.20 \\
\hline 4 & 86.77 & 7.48 \\
\hline 5 & 69.02 & 8.58 \\
\hline 6 & 93.90 & 2.37 \\
\hline 7 & 95.70 & 1.79 \\
\hline 8 & 80.67 & 2.21 \\
\hline 9 & 94.02 & 4.09 \\
\hline 10 & 89.65 & 6.21 \\
\hline 12 & 92.22 & 1.67 \\
\hline 13 & 94.22 & 2.59 \\
\hline 14 & 70.60 & 3.99 \\
\hline 15 & 94.16 & 1.27 \\
\hline 16 & 92.57 & 2.92 \\
\hline 18 & 94.57 & 4.09 \\
\hline
\end{tabular}

Based on the knowledge of the chemical composition of the tested limestones, they were found to have large discrepancies in the obtained results regarding the content of individual components, in particular $\mathrm{CaCO}_{3}$ content $(69.22-95.7 \%)$ and the total contribution of limestone pollutants $\mathrm{Fe}_{2} \mathrm{O}_{3}+\mathrm{K}_{2} \mathrm{O}+\mathrm{SO}_{3}+\mathrm{Na}_{2} \mathrm{O}+\mathrm{MgO}+\mathrm{Al}_{2} \mathrm{O}_{3}+\mathrm{SiO}_{2}+$ NR + Moisture (1.27-10.52\%).

Comparing the chemical composition of limestone test samples with the standards given in [12], it appears that not all of them meet the required values of shares of individual components.

\subsection{Analysis of the grain composition of the tested limestone samples}

The analysis of the grain composition of the investigated limestone samples was carried out with a Malvern Mastersizer S laser analyzer. A summary of the grain composition of the tested limestone samples is presented in Table 2.

In the table the following designations are used:

$\mathrm{D}(\mathrm{v}, 0.1)$ - grain diameter for a $10 \%$ volume distribution, $\mu \mathrm{m}$

$\mathrm{D}(\mathrm{v}, 0.5)$ - average value of the $50 \%$ volume distribution, $\mu \mathrm{m}$

$\mathrm{D}(\mathrm{v}, 0.9)$ - grain diameter for a $90 \%$ volume distribution, $\mu \mathrm{m}$

$\mathrm{D}[4,3]$ - average diameter of the weighed volume, $\mu \mathrm{m}$

$\mathrm{D}[3,2]$ - average diameter of the weighed area, $\mu \mathrm{m}$

S.A.A. - specific surface area of particles per unit of mass, $\mathrm{m}^{2} / \mathrm{g}$

The results are formed in the following ranges of values:

$\mathrm{D}(\mathrm{v}, 0.1)$ : 2.23(Limestone sample number 4) - 131.58 (Limestone sample number 8 ), $\mu \mathrm{m}$

$\mathrm{D}(\mathrm{v}, 0.5)$ : 8.11(Limestone sample number 14) - 537.18 (Limestone sample number 9), $\mu \mathrm{m}$

D (v, 0.9): 39.64(Limestone sample number 12) -1450.37 (Limestone sample number 16), $\mu \mathrm{m}$

$\mathrm{D}[4,3]$ : 25.36 (Limestone sample number 6) - 612.38 (Limestone sample number 16), $\mu \mathrm{m}$

D[3,2]: 5.55 (Limestone sample number 14) - 124.37 (Limestone sample number 8 ), $\mu \mathrm{m}$

S.A.A. : 0.02 (Limestone sample number 8) - 0.42 (Limestone sample number 14 ), $\mathrm{m}^{2} / \mathrm{g}$ 
Table 2. Summary data on grain composition test samples of limestone.

\begin{tabular}{|c|c|c|c|c|c|c|}
\hline $\begin{array}{c}\text { Limestone } \\
\text { sample } \\
\text { number }\end{array}$ & $\mathbf{D}(\mathbf{v}, \mathbf{0 1})$ & $\mathbf{D}[\mathbf{4 , 3}]$ & $\mathbf{D}(\mathbf{v}, \mathbf{0 5})$ & $\mathbf{S . S . A .}$ & $\mathbf{D}[\mathbf{3 , 2}]$ & $\mathbf{D}(\mathbf{v}, \mathbf{0 9})$ \\
\hline 2 & 2.91 & 39.46 & 13.96 & 0.30 & 7.78 & 116.76 \\
\hline 3 & 2.98 & 30.60 & 15.00 & 0.29 & 7.96 & 81.80 \\
\hline 4 & 2.23 & 38.76 & 14.04 & 0.37 & 6.20 & 107.09 \\
\hline 5 & 2.39 & 26.73 & 8.75 & 0.40 & 5.74 & 43.51 \\
\hline 6 & 3.09 & 25.36 & 13.58 & 0.29 & 7.83 & 52.19 \\
\hline 7 & 12.34 & 249.94 & 224.96 & 0.08 & 29.16 & 506.04 \\
\hline 8 & 131.58 & 279.93 & 258.68 & 0.02 & 124.37 & 466.72 \\
\hline 9 & 11.95 & 583.57 & 537.18 & 0.07 & 35.37 & 1255.62 \\
\hline 10 & 3.04 & 54.71 & 29.44 & 0.25 & 9.10 & 142.37 \\
\hline 12 & 2.32 & 30.53 & 10.35 & 0.36 & 6.45 & 39.64 \\
\hline 13 & 2.56 & 40.58 & 9.17 & 0.37 & 6.32 & 132.20 \\
\hline 14 & 2.36 & 28.77 & 8.11 & 0.42 & 5.55 & 57.47 \\
\hline 15 & 4.05 & 431.99 & 314.52 & 0.16 & 14.81 & 1076.42 \\
\hline 16 & 8.25 & 612.38 & 490.33 & 0.08 & 27.03 & 1450.37 \\
\hline 18 & 2.66 & 34.35 & 11.76 & 0.33 & 6.97 & 102.88 \\
\hline
\end{tabular}

\subsection{Analysis of the reactivity of the tested limestone samples}

The test samples were ground before screening and sieved through a $0.045 \mathrm{~mm}$ square mesh screen. The tests were carried out for samples containing $40 \mathrm{mmol}$ of reactive limestone $\left(\mathrm{CaCO}_{3}+\mathrm{MgCO}_{3}\right)$ or properly calcined limestone $(\mathrm{CaO}+\mathrm{MgO})$. The results of the study were presented as the degree of calcium conversion as a function of titration time.

Analysis of the obtained results of the reactivity tests of 10 limestones listed in Table 3 showed that it is dependent on the degree of fragmentation of the tested limestone sample and its calcium carbonate content $\left(\mathrm{CaCO}_{3}\right)$.

Table 3. Summary results of the reactivity of limestone and the content of $\mathrm{CaCO}_{3}$.

\begin{tabular}{|c|c|c|c|}
\hline $\begin{array}{c}\text { Limestone sample } \\
\text { number }\end{array}$ & $\mathbf{C a C O}_{\mathbf{3}}$ share & $\mathbf{D}(\mathbf{v} ; \mathbf{0 , 9})$ & $\mathbf{R}_{\mathbf{6 0}}$ \\
\cline { 2 - 4 } & $\boldsymbol{\%}$ & $\mu \mathrm{m}$ & $\mathbf{\%}$ \\
\hline 12 & 92.22 & 39.64 & 98.11 \\
\hline 13 & 94.22 & 132.20 & 96.16 \\
\hline 18 & 94.57 & 102.88 & 96.16 \\
\hline 7 & 95.70 & 506.04 & 94.99 \\
\hline 6 & 93.90 & 52.19 & 92.10 \\
\hline 8 & 80.67 & 466.72 & 91.72 \\
\hline 9 & 94.02 & 1255.62 & 91.31 \\
\hline 10 & 89.65 & 142.37 & 90.39 \\
\hline 3 & 90.32 & 81.80 & 89.98 \\
\hline 2 & 82.63 & 116.76 & 88.47 \\
\hline
\end{tabular}

$\mathrm{D}(\mathrm{v} ; 0,9)$ - grain diameter for a $90 \%$ volume distribution

$\mathrm{R}_{60}$ - reactivity after 60 minutes of testing

Knowledge of the degree of reactivity, i.e. the kinetic parameter of lime limestone dissolving, enables the selection of parameters for the flue gas desulfurization process and facilitates the design process of absorbers. 


\section{Studies of the effectiveness of gas phase desulfurization in an aqueous limestone slurry}

\subsection{Laboratory stand for gas phase desulfurization in an aqueous limestone slurry}

For the research of the gas phase desulfurization process in an aqueous limestone slurry, a laboratory stand was designed and constructed, the diagram of which is shown in Fig. 1

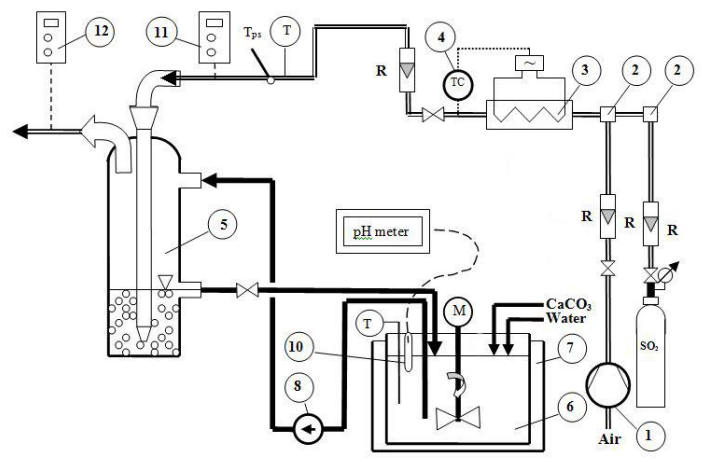

Fig 1. Test stand schematic. 1 - blower, 2 - mixer, 3 - electric heater, 4 - thermostat, 5 - absorption reactor, 6 - reservoir of absorption slurry, 7 - water bath, 8 - diaphragm pump, $10-\mathrm{pH}$ electrode, 11 , 12 - Dioxor II firmy Bacharach analyzer, M- mechanical stirrer, $\mathrm{T}$ - thermometer, R - rotameter

The main element of the test stand is the reservoir of the absorption slurry (6), immersed during the tests in the water bath (7), that task is to stabilize the temperature of the slurry in the tank (6) at $323-338 \mathrm{~K}$. The total capacity of this tank is $0.5 \mathrm{dm}^{3}$. The operating volume of the absorption suspension was set at $0.1 \mathrm{dm}^{3}$. A limestone $\left(\mathrm{CaCO}_{3}\right)$ with a fixed Sauter particle diameter was dosed into the reservoir, and then it was flooded with distilled water in an amount sufficient to achieve the intended concentration of the absorption suspension ( $1 \%$ by mass). The reactor-absorber (5) was fed a gas phase consisting of a mixture of gaseous components: $\mathrm{SO}_{2}$ and air. The concentration of $\mathrm{SO}_{2}$ in the gas phase was 1100-1999 ppm. The temperature of the gas phase, after mixing the components, was stabilized in an electric heater (3) at $50^{\circ} \mathrm{C}$. The volume flow of the gas phase flowing through the absorber was about $60 \mathrm{dm}^{3} / \mathrm{h}$.

\subsection{Test results of the effectiveness of gas phase desulfurization in an aqueous limestone slurry}

The examples of results are presented in graphical form (Figure 2-4) as a dependence of the effectiveness of gas phase desulfurization and $\mathrm{pH}$ value of the absorption slurry from the retention time and efficiency of gas phase desulfurization from the $\mathrm{pH}$ value of the absorption slurry. 


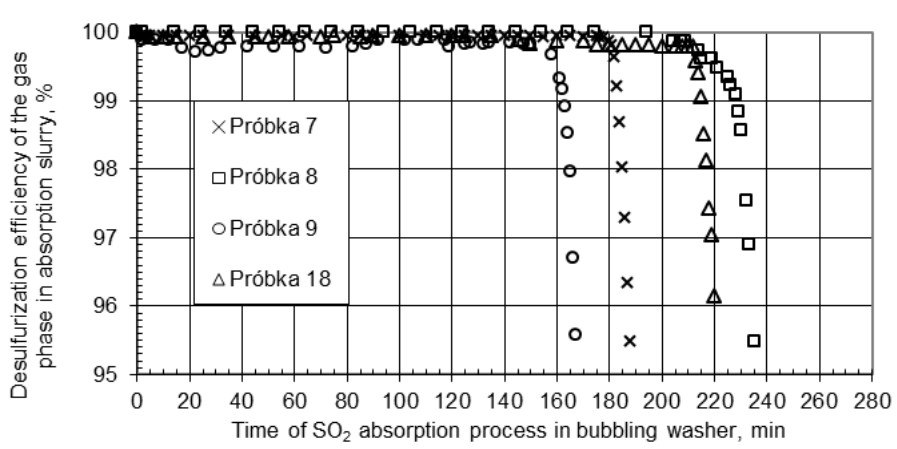

Fig. 2. Dependence of the gas phase desulfurization efficiency in the absorption slurry from time of the absorption process of $\mathrm{SO}_{2}$ in the bubble washer (fraction $\leq 20 \mu \mathrm{m}$ ).

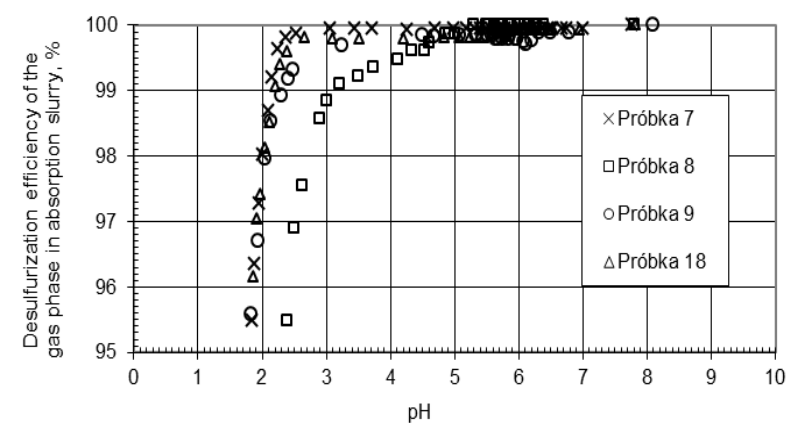

Fig. 3. Dependence of the gas phase desulfurization efficiency in the absorption slurry from $\mathrm{pH}$ of the absorption suspension (fraction $\leq 20 \mu \mathrm{m}$ ).

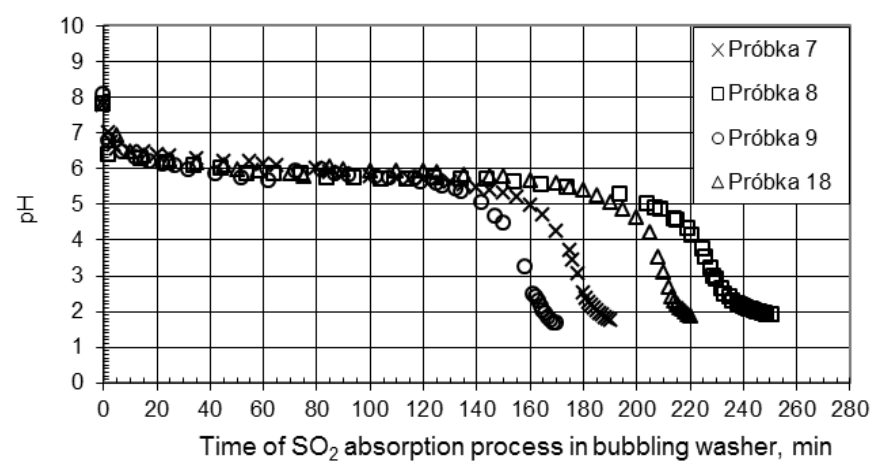

Fig. 4. Dependence of the $\mathrm{pH}$ of the absorption suspension from time of the absorption process of $\mathrm{SO}_{2}$ in the bubble washer (fraction $\leq 20 \mu \mathrm{m}$ ).

As the particle size in the absorption slurry increases, by using larger ground limestone fractions, the $\mathrm{pH}$ of the slurry during $\mathrm{SO}_{2}$ absorption decreases.

Based on the course of changes in the $\mathrm{pH}$ value of the slurry circulating in the absorption cycle over time, the suitability of each sorbent tested for FGD on an industrial scale can be estimated. And in this analysis, the volume of the absorption liquid tank and the retention time of this liquid in the tank can be further determined. 
The initial $\mathrm{pH}$ of the absorbent slurry in each $\mathrm{SO}_{2}$ absorption experiment is relatively high. This results in high efficiency of gas phase desulfurization. Then, as the $\mathrm{SO}_{2}$ absorption process continues, a decrease in the $\mathrm{pH}$ value is observed.

In the case of factions characterized by large grain size, the efficiency of the process decreases rapidly in the initial stage of the process, then stabilizes, and in the case of some of the samples it was even observed to increase. This is due to the small contact surface for large grains.

\section{Modelling of the effectiveness of gas phase desulfurization in an aquaeous slurry of limestone}

To carry out a regression analysis there are summarized 959 observations. To illustrate the influence of selected parameters on the efficiency of gas phase desulfurization in a vertical spray absorber, a multiple regression was carried out, which led to a correlation equation in the form of:

$$
\eta_{S O_{2}}=1-\exp \left[-\exp \left(-0,00102 d_{i . f}+0,00538 R_{i 60}+0,14467 p H+0,00052 C_{1 S O_{2}}-0,00123 t_{z a w}\right)\right]
$$

$d_{i, f}$ - average diameter of the ground limestone particle fraction, $\mu \mathrm{m}$,

$R_{60}$ - limestone reactivity (after 60 minutes), $\%$,

$\mathrm{pH}-$ the $\mathrm{pH}$ value of the absorption slurry,

$\mathrm{C}_{1 \mathrm{SO}_{2}}-\mathrm{SO}_{2}$ concentration in the gas phase at the inlet to the installation, ppm,

$t_{\text {zaw }}-$ temperature of the absorption slurry at the reactor inlet, ${ }^{\circ} \mathrm{C}$.

\section{Summary}

After analyzing the results determining the effect of limestone fragmentation on the initial $\mathrm{pH}$ of the absorption slurry, the $\mathrm{pH}$ value and efficiency of gas phase desulfurization, it can be noticed that after the same time of desulfurization process, ultra fine fractions are characterized by the highest efficiency of removing $\mathrm{SO}_{2}$ from the gas phase and the smallest decrease in value $\mathrm{pH}$.

The coarse fractions are characterized by the highest drop in the $\mathrm{pH}$ value and show the least effective removal of $\mathrm{SO}_{2}$ from the gas phase.

The initial $\mathrm{pH}$ value of the absorption suspension affects the efficiency of the gas phase desulfurization process only at the initial stage of the process.

The residence time of the absorption slurry in the reactor and the slurry flow rate are important parameters of the gas phase desulfurization process. Insufficient volume of the slurry in the reactor may be the reason for the low degree of utilization of limestone in the gas phase desulfurization process. Too large volume of absorption slurry in the reactor (no outflow into the absorption slurry tank) affects the abrupt fluctuation of the $\mathrm{pH}$ value in the tank (a sharp drop and then a return to the stabilized value).

The $\mathrm{pH}$ of the absorption slurry decreases with increasing its contact time with the gas phase. Incident jumps in the $\mathrm{pH}$ value are associated with the dissolution process of larger grains and disturbances of the mixing process in the absorption slurry tank.

Using sorbents with a higher degree of milling, it is possible to increase the rate of their dissolution, rapid increase of $\mathrm{pH}$, reduction of retention time, reduction of $\mathrm{L} / \mathrm{G}$ ratio and reduction of investment and operating costs of installations [13, 14]. 


\section{References}

1. N. Lysek, Sorbenty do odsiarczania gazów. Produkcja i zastosowanie (Opolwap S.A., Tarnów Opolski, 1997)

2. E. Hycnar, T. Ratajczak, W. Jończyk, Sorbenty Mineralne, Surowce, Energetyka, Ochrona Środowiska, Nowoczesne Technologie (AGH, Kraków, 2013)

3. J. Hehlmann, M. Jodkowski, Badania procesu mokrego rozdrabniania maczki kamienia wapiennego oraz wptywu rozdrobnienia na efektywność odsiarczania spalin (Środkowo-Pomorskie Towarzystwo Naukowe Ochrony Środowiska, 2009)

4. W. Mokrosz, Chemik, Nauka - Technika - Rynek, 6 (2005)

5. M. Głomba, E. Szmigielska, Environment Protection Engineering 37, 2 (2011)

6. S. Zarkanitis, S.V. Sotirchos, AIChE Journal 35, 5 (1989)

7. G. Butenuth, M.L. Frey, R. Gotthardt, W. Kasig, Zement-Kalk-Gips, 9 (1993)

8. A. Hałat, W. Kordylewski, M. Głomba, D. Łuszkiewicz, Environment Protection Engineering 42, 2 (2016)

9. M. Głomba, E. Szmigielska, Czasopismo Techniczne Chemia 108, 8 (2011)

10. B. Gullett, Reactivity of Solid, 3 (1987)

11. T. Fulczyk, J. Lassak, Doświadczenia eksploatacyjne instalacji odsiarczania spalin (Energopomiar, Tatrzańska Łomnica, 2009)

12. B. Burzała, K. Wojnar, Doświadczenia eksploatacyjne IOS (Energopomiar, Tatrzańska Łomnica, 2011)

13. W. Mokrosz, Ochrona powietrza w teorii i praktyce (IPIŚ PAN, Zabrze, 2008)

14. J. Warych, M. Szymanowski, Ochrona Powietrza i Problemy Odpadów 35, 3 (2001) 